\title{
Effect of Precast Concrete Pavement Albedo on the Climate Change Mitigation in Spain
}

\author{
Miguel Ángel Sanjuán ${ }^{1, * \mathbb{B}}$, Ángel Morales ${ }^{2}$ and Aniceto Zaragoza ${ }^{3}$ \\ 1 Spanish Institute of Cement and Its Applications (IECA), 28003 Madrid, Spain \\ 2 Concentrating Solar Power Unit, The Center for Energy, Environmental and Technological \\ Research (CIEMAT), Avenida Complutense, 40, 29040 Madrid, Spain; angel.morales@ciemat.es \\ 3 Department of Transportation, Madrid Polytechnic Institute, 28003 Madrid, Spain; azaragoza@oficemen.com \\ * Correspondence: masanjuan@ieca.es; Tel.: +34-914429166
}

Citation: Sanjuán, M.Á.; Morales, Á.; Zaragoza, A. Effect of Precast

Concrete Pavement Albedo on the Climate Change Mitigation in Spain. Sustainability 2021,13,11448. https:// doi.org/10.3390/su132011448

Academic Editor:

Emilio Bastidas-Arteaga

Received: 29 September 2021

Accepted: 14 October 2021

Published: 16 October 2021

Publisher's Note: MDPI stays neutral with regard to jurisdictional claims in published maps and institutional affiliations.

Copyright: () 2021 by the authors. Licensee MDPI, Basel, Switzerland. This article is an open access article distributed under the terms and conditions of the Creative Commons Attribution (CC BY) license (https:// creativecommons.org/licenses/by/ $4.0 /)$.

\begin{abstract}
The widespread use of solar-reflective concrete pavements can mitigate climatic change and urban heat islands (UHI) by cooling the pavement surfaces that are made of concrete instead of asphalt. The methodology that was followed is based on the comparison between the asphalt and concrete albedo effects in a specific application and area. In this study, we found that a reduction of temperature in the terrestrial surface, equivalent to the removal of $25-75 \mathrm{kgCO}_{2} / \mathrm{m}^{2}$, could be achieved. Considering all the motorways and freeways of Spain, which is the third country in the world in $\mathrm{km}$, a yearly equivalent carbon dioxide emissions reduction of 13-27 million tons could be reached. This value is quite high considering that the cement sector worldwide released about 2.9 Gigatons of carbon dioxide in 2016. Therefore, there is a positive balance in the use of concrete pavements. Furthermore, concrete is a material completely recyclable at the end of its service life and concrete pavement construction requires local resources, avoiding GHG emissions due to transport. An increase in the Spanish freeway network albedo by replacing asphalt pavements with concrete ones will improve the local climate change mitigation.
\end{abstract}

Keywords: sustainable applied materials; construction; concrete; $\mathrm{CO}_{2}$ emission; sustainability; albedo; solar reflectance; pavement; cement; asphalt; policy

\section{Introduction}

Albedo or solar reflectivity is a thermal property defined as the ratio of the reflected to the incident solar radiation at the earth surface. Therefore, albedo is an indicator of the reflecting capacity of a given surface. This dimensionless parameter is zero for nonreflecting dark surfaces, whereas this value is unity for total reflection of white surfaces (100\% reflected). This phenomenon has been well known since antiquity. For instance, all houses in some Mediterranean villages are painted white to reflect the sun light and make buildings cooler during the summer season (e.g., Ronda in Málaga, Mojácar in Almería, both in Spain, and so on). Accordingly, cooling the cities worldwide by reflecting sunlight with solar reflective surfaces of roofs and pavements is an easy and cost-effective lever to cool the planet, which will cause other global changes in climate. Furthermore, it could be an effective Urban Heat Island (UHI)-mitigating strategy and a way to reduce greenhouse gas (GHG) emission in urban areas [1,2].

Rosenfeld et al. [3] found that an increase of albedo by 0.25 in $1250 \mathrm{~km}^{2}$ of pavement would save \$15 million every year of cooling energy in Los Angeles [3], and Cotana et al. [4] reported that a $115,000 \mathrm{~m}^{2}$ high-albedo surface area may decrease 16,000 tons of $\mathrm{CO}_{2 \mathrm{eq}}$, if implemented for 30 years [4]. About $4500 \mathrm{~m}^{2}$ of a weathered pavement made of asphalt, concrete, and dark materials was replaced with high solar reflectance paving materials in an urban park in Athens, Greece, and it was found that the highest daily air temperature was lowered by $1.9^{\circ} \mathrm{C}$ and the surface temperature was reduced by $12{ }^{\circ} \mathrm{C}$ in the core zone of this Athenian Park [5]. Battisti et al. [6] conducted a study in Rome and concluded that cool 
pavements perform a mitigation of heat stress compared to traditional sealed surfaces, i.e., asphalt. In a similar manner, Diz-Mellado et al. [7] considered that cool paving materials provide a reduction in the peak surface temperature. Therefore, the material composition, textures, and colors of pavements largely determine their climatic behavior. Another study by Pisello et al. [8] proved that the measured albedo of highly reflective stone is higher than the normally used gravel. In addition, they found that the homogeneity of the aggregate surface has a beneficial effect on the albedo value and surface temperatures in the daytime. Moreover, the albedo values decrease with the grain dimension.

Sen et al. [9] reported a decreased air temperature by $0.2-0.4{ }^{\circ} \mathrm{C}$ when replacing traditional pavements with reflective concrete pavements. They suggested that changing pavements into reflective surfaces could be the most effective strategy for mitigating heat. Therefore, this strategy for mitigating climate change could be applied to high-traffic roads. Furthermore, by increasing the freeways' and motorways' paved surface albedo, they will remain cooler, decreasing heat convection from pavement to air. Accordingly, reflective pavements are a passive mitigation strategy gaining in interest to reduce climate change effects. Conventional pavements, i.e., asphalt, absorb and store solar radiation on account of their dark surface. However, the albedo of the pavement can increase with the use of concrete instead of asphalt or the utilization of colored constituents to produce concrete pavements.

According to Fernández-Antolín et al. [10], the knowledge development and transfer at the training level in sustainable architecture and civil engineering is urgent. Tsoka et al. [11] reviewed previous studies on the cooling potential of high-albedo pavements, and the use of reflective materials is considered as a passive mitigation strategy [12], which is highly recommended [13].

It is evident that a small increase of 0.01 in albedo can have significant effects on both the local environment and the climate change mitigation. Therefore, the ambient air temperature will be reduced by increasing the solar reflectance of pavements, for instance, by removing and replacing the existing pavements made of asphalt with high solar reflectance paving concrete.

Concrete is a mixture of Portland cement, water, chemical admixtures, fine aggregates (sand), coarse aggregates (particles that retain on $4.75 \mathrm{~mm}$ sieve), and sometimes supplementary cementitious materials (SCM), such as coal fly ash and silica fume. Its external appearance (color, smoothness, and brightness) depends on the raw materials characteristics, progress of the Portland cement hydration and pozzolanic reactions, and environmental interactions (durability, ageing, and fouling). Portland cements are mainly gray or white, but colored cements can be produced by adding inorganic pigments to white cements. Grey color in Portland cements is primarily due to iron, chromium, and manganese oxides, whereas white cements contain small amounts of the mentioned oxides $\left(\mathrm{Fe}_{2} \mathrm{O}_{3}<0.4 \% ; \mathrm{Cr}_{2} \mathrm{O}_{3}<0.003 \%\right.$ and $\left.\mathrm{Mn}_{2} \mathrm{O}_{3}<0.03 \%\right)$ [14]. Moreover, concrete surfaces can be covered by a thin white layer of calcium carbonate formed by carbonation, i.e., the reaction of calcium hydroxide present in the Portland cement with the atmospheric carbon dioxide [15]. Similarly, efflorescence in concrete forms whitish-colored salt deposition on the surface.

Aggregates make up about $60-80 \%$ of the total volume of the concrete mix, and they influence the properties of the freshly mixed and hardened concrete, mix design proportions, and final product economy. Furthermore, albedo is affected by the aggregate type, where concrete made with darker aggregates shows lower albedo compared to concretes made with lighter ones, such as limestone aggregate [16]. Consequently, the selection of aggregates is a substantive process.

According to Levinson et al. [17], the albedo of mature smooth-surface concrete ranges from to 0.41 to 0.77 , and white Portland cement smooth concrete albedo is about 0.18-0.39 higher than that of grey Portland cement smooth concrete. Moreover, concrete albedo increases as the Portland cement hydration reaction proceeds during the first six weeks (about 0.08) [17]. Blast-furnace cements with $30 \%$ of ground granulated blast furnace slag 
(GGBFS) can increase the Solar Reflectance Index (SRI) of concretes made with common grey cement by $38 \%$ [16]. By contrast, weathering, dirt, and abrasion lower the concrete albedo by $0.05-0.19$ [17]. Furthermore, concrete albedo is reduced by about 0.23 when the concrete surface is wetted by rainwater. Accordingly, white-cement smooth dry concretes made with limestone aggregates are expected to be the most reflective. As a starting point, a range of values of albedo for new concrete of $0.35-0.40$ and $0.25-0.30$ for weathered concrete could be agreed. By comparison, the initial value of albedo for asphalt is $0.05-0.10$, nevertheless, as time goes by, it increases to about $0.10-0.20$. Nevertheless, concrete currently has a smaller overall share in paving compared to asphalt. Then, in order to motivate building designers to reduce heat islands, Leadership in Energy and Environmental Design (LEED) certification (Credit 7.1) considers the replacement of constructed surfaces such as roads with open grid paving or designing with high-albedo materials, such as concrete, to lower heat absorption [18]. Pavement visible reflectance is relevant to civil engineers involved in designing the lane markings on the roads and their artificial lighting. Nevertheless, solar reflectance is different from its visible reflectance on the pavement surface area because visible light (wavelengths range: $400-700 \mathrm{~nm}$ ) commitment represents only $39 \%$ of the total energy in the solar emission spectrum (wavelength range: 300-2500 nm), while infrared light (700-2500 nm) and ultraviolet light (300-400 nm) account for about $55 \%$ and $6 \%$, respectively [19]. Given that, simple visual appearance of a lighter surface might not necessarily mean a higher solar reflectance.

Saulat et al. [20] reviewed the applications of calcium carbonate whisker, which is a class of inorganic fiber used as a reinforcing material in different composites to enhance their properties [21]. This material is white and, probably, it will be able to provide a high reflectance to the concrete pavements made with it. Furthermore, polypropylene fibers for concrete roads [22] can also take on a positive role in the concrete pavement's albedo increase. By contrast, silica-fume used in concrete roads for thickness reduction [23] makes a darker concrete. All new materials used in concrete paving should be tested and optimized from an albedo point of view because if albedo rises, more light gets reflected back to space and the planet gets cooler.

There are some values of albedo for different materials used in pavements reported in the literature. A review of the materials that can be used in the manufacture of high solar reflectance concrete is shown in Table $1[8,17,24]$. They can be compared with the asphalt albedo of 0.1 (new) or 0.2 (old) [17].

Table 1. Albedo values for different concrete constituents (Portland cement and aggregates) and concretes.

\begin{tabular}{cc}
\hline Concrete constituent & Albedo \\
\hline White Portland cement. & 0.87 \\
Ground granulated blast-furnace cements. & $0.71-0.75$ \\
Gray Portland cement. & $0.32-0.47$ \\
Coal fly ash. & $0.28-0.55$ \\
\hline Dark grey riverbed sand (quartz, clay minerals, mica). & 0.20 \\
Black and red rock (granite). & 0.19 \\
White rock (plagioclase). & 0.49 \\
Limestone fine aggregate. & 0.42 \\
Limestone coarse aggregate. & 0.42 \\
Gold and white rock (chert, iron impurities). & 0.55 \\
Fine grain natural gravel & 0.62 \\
\hline Concrete composed of ordinary Portland cement, fine aggregate from & 0.64 \\
crushed limestone, and light-colored slag cement. & 0.64 \\
\hline
\end{tabular}

Concern over local aspects of climate change has increased in recent years. Given that, instead of considering the climate change assessment on a continental or global scale, 
local climate change evaluation studies smaller units of area, such as countries. Following this approach, the present work analyzes the effect of an albedo increase by modifying low-albedo surface area pavements made with asphalt to high-albedo ones made with concrete in Spain.

Spain's national freeway system dates back to the time of King Carlos III. At that time, the main roads were built radiating from Madrid. Spain's road network has 165,445 km, as of December 31, 2019 [25]. In the 1960s, Spain started to build toll freeways and freeways. Currently, there are 17,377 km of freeways (2021), which is the biggest European network and fourth worldwide, after the USA, India, and China [26].

The goals of this experimental study are to: i) perform measurements of albedo on different precast pavement materials including prototypes not currently found on the market; ii) compare the albedo values for different materials commonly used in pavements; and iii) estimate the effect of the use of high-albedo materials on climate change mitigation due to the pavement temperature decrease. Therefore, an increase in the Spanish freeway network albedo by replacing asphalt pavements with concrete ones is studied and the ulterior effect on the local climatic change is discussed in this paper.

\section{Research Motivation and Significance}

Concrete is the most widely used construction material worldwide. In its simplest form, concrete consists of fine and coarse aggregates bonded together by Portland cement and water. Furthermore, there is an appropriate amount of chemistry involved in finding the right combination of ingredients. Its production is energy-intensive, and the manufacture of Portland cement accounts for $7.4 \%$ of the world's $\mathrm{CO}_{2}$ emission $(2.9$ Gtons in 2016) [27]. Fortunately, it should be recalled that efforts are made to take effective measures to reduce its impact, or at least to look at new ways to use cement-based materials in a beneficial way from a sustainability point of view. Therefore, new concrete materials will be more green than grey. In this respect, it is striking that the pavement's albedo will play an important role, in the near future, in the climate change mitigation. According to the IPCC AR6 Climate Change 2021 report "The Physical Science Basis" [28], earth is warmer $\left(1.1^{\circ} \mathrm{C}\right)$ than it has been in 125,000 years, but regulators can still prevent the worst consequences by defining the most adequate materials. Accordingly, the future of the planet depends on the choices that mankind makes today.

This study will be beneficial to society in general as well as the science and technology development, which are closely linked to economic development. The research significance of current work relies on the fact that the concrete pavements can be designed with high-reflectance constituents to achieve a high albedo. The research motivation is to open up better climate change mitigation levers to regulatory authorities with the use of concrete pavements.

A research gap in this study is the unexplored effect of the age on the concrete albedo. As concrete ages, it tends to darken because aging leads to high levels of dirt particles and tire wear on the pavements. Therefore, it is expected that older concretes have lower albedos than new ones.

\section{Materials and Methods}

\subsection{Pavement Materials for Measurement}

Precast concrete pavements made by different materials and provided by two different producers (Pavimentos de Tudela (PVT), Navarra, Spain and Sailo, Toledo, Spain) were used in the present experimental program (Figures 1 and 2, respectively). The use of precast concrete pavement is an emerging technology worldwide for application to innovative construction solutions and rehabilitation of existing pavements. 


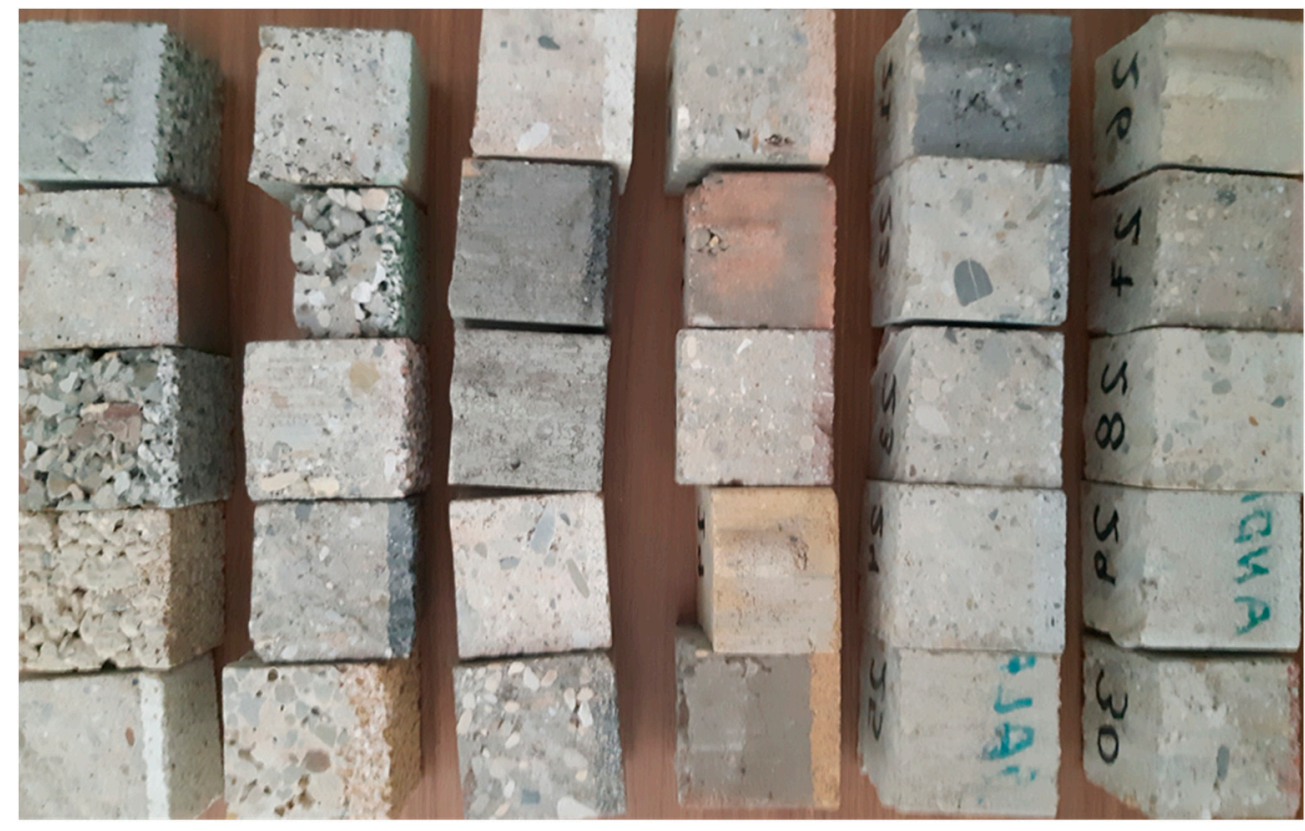

Figure 1. PVT samples, from top to bottom: first column: 1-5, second column: 6-10; and so on.

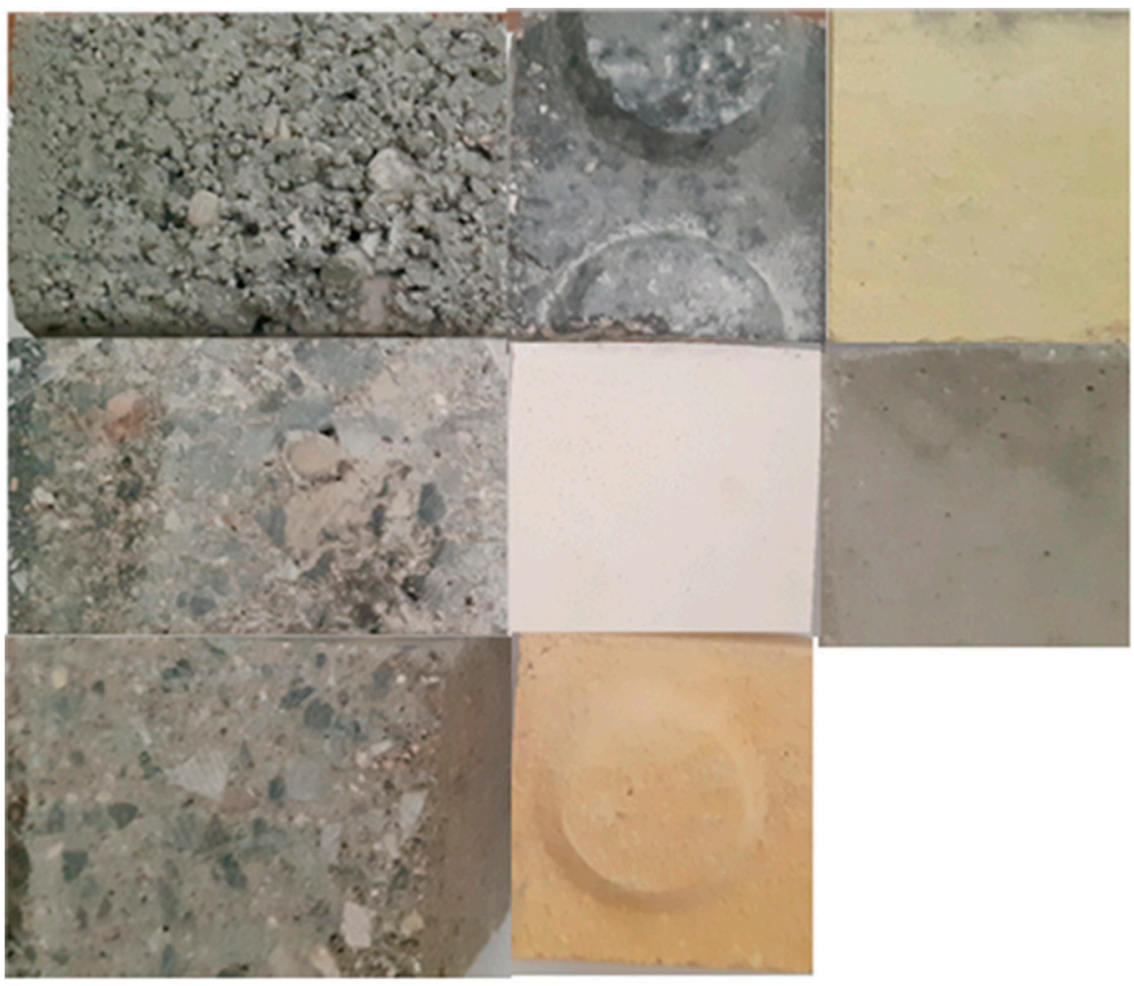

Figure 2. Sailo samples, from top to bottom: first column: 1-3, second column: 4-6; and third column 7-8.

PVT pavements were made with a common cement CEM I $52.5 \mathrm{R}$ according to the European standard, grey or white, depending on the final color of the sample. Siliceous and calcareous sand $(0-2 \mathrm{~mm})$ was used. The calcareous sand was marble powder.

Sailo pavements were made with grey or white CEM I $42.5 \mathrm{R}$ according to the European standard and siliceous aggregates (sand: $0-4 \mathrm{~mm}$ ).

Table 2 summarizes the codes and main characteristics of all the tested precast concrete pavements. 
Table 2. Description and codification of the tested samples.

\begin{tabular}{|c|c|c|c|c|}
\hline PVT Code & Denomination and Description & Cement and Aggregate Types & $\begin{array}{l}\text { Sailo } \\
\text { Code }\end{array}$ & Description \\
\hline PVT-1 & Outside finish: exposed grey aggregate & white cement & Sailo-1 & Gray cobblestone \\
\hline PVT-2 & Fire & grey cement & Sailo-2 & Black cobblestone \\
\hline PVT-3 & Eco Draining Travertine (porous aspect) & white cement, granitic sand & Sailo-3 & Brown cobblestone \\
\hline PVT-4 & Eco Draining Steel (porous aspect) & white cement, granitic sand & Sailo-4 & Black tile \\
\hline PVT-5 & Outside finish: exposed white aggregate & white cement and clear sand & Sailo-5 & $\begin{array}{l}\text { White color precast } \\
\text { concrete }\end{array}$ \\
\hline PVT-6 & Grass & white cement & Sailo-6 & $\begin{array}{c}\text { Albero (chalky sand) } \\
\text { yellow tile }\end{array}$ \\
\hline PVT-7 & Eco Draining Green & white cement, granitic sand & Sailo-7 & Pantone ${ }^{\circledR}$ Yellow 012 tile \\
\hline PVT-8 & Outside finish: exposed salmon aggregate & white cement & Sailo-8 & $\begin{array}{c}\text { Gray color precast } \\
\text { concrete }\end{array}$ \\
\hline PVT-9 & Outside finish: exposed black aggregate & grey cement & & \\
\hline PVT-10 & Eco Draining russet & white cement, granitic sand & & \\
\hline PVT-11 & Snow & white cement and clear sand & & \\
\hline PVT-12 & Mica & grey cement & & \\
\hline PVT-13 & Steel & white cement & & \\
\hline PVT-14 & Travertine & white cement & & \\
\hline PVT-15 & Oxide & white \& grey cement & & \\
\hline PVT-16 & Earth-colored pavement & white \& grey cement & & \\
\hline PVT-17 & Sand & white cement & & \\
\hline PVT-18 & Mocha & grey cement & & \\
\hline PVT-19 & Bardenas & white cement & & \\
\hline PVT-20 & Cárdeno & white cement & & \\
\hline PVT-21 & Baztán & grey cement & & \\
\hline PVT-22 & Urbasa & white cement & & \\
\hline PVT-23 & Roncal & grey cement & & \\
\hline PVT-24 & Aralar & white \& grey cement & & \\
\hline PVT-25 & Salazar & white cement & & \\
\hline PVT-26 & Aneto & white cement & & \\
\hline PVT-27 & Irati & grey cement & & \\
\hline PVT-28 & Ulzama & white cement and clear sand & & \\
\hline PVT-29 & Andía & white cement and clear sand & & \\
\hline PVT-30 & Leather & white \& grey cement & & \\
\hline
\end{tabular}

\subsection{Measurement Method and Equipment}

Concrete samples were taken from a variety of commercial precast pavements made with different Portland cements, sands, and rocks. Their albedos were measured in cut concrete surfaces. Since wetting markedly modifies the reflectance of concrete surfaces, they were dried prior to albedo measurement.

Albedo, or solar reflectance, is the percentage of solar energy reflected by a surface. Researchers have developed methods to determine solar reflectance by measuring how well a material reflects energy at each wavelength, then calculating the weighted average of these values.

In order to calculate albedo, hemispherical reflectance of pavements is measured with a double beam UV/VIS/NIR Perkin Elmer Lambda 950 Spectrophotometer, with a $10 \mathrm{~cm}$ integrating sphere coated with a diffusing material. The integrating sphere allows to measure the amount of incident radiation on the sample surface that is reflected in all directions.

Four readings of each pavement sample were measured $(300-2500 \mathrm{~nm})$, and albedos of concrete pavements were calculated by averaging reflectance measurements with air mass of 1.5 on the global solar radiation spectrum:

$$
\text { Albedo }=\frac{\int_{0.3 \mu \mathrm{m}}^{2.5 \mu \mathrm{m}} \rho_{\lambda} G_{b}(\lambda) d \lambda}{\int_{0.3 \mu \mathrm{m}}^{2.5 \mu \mathrm{m}} G_{b}(\lambda) d \lambda}
$$


where $\rho_{\lambda}$ is the hemispherical reflectance for each wavelength value and $G_{b}(\lambda)$ is the spectral solar irradiance AM1.5G (ASTM G173-03).

Figure 3 shows a schematic diagram of the testing procedure.

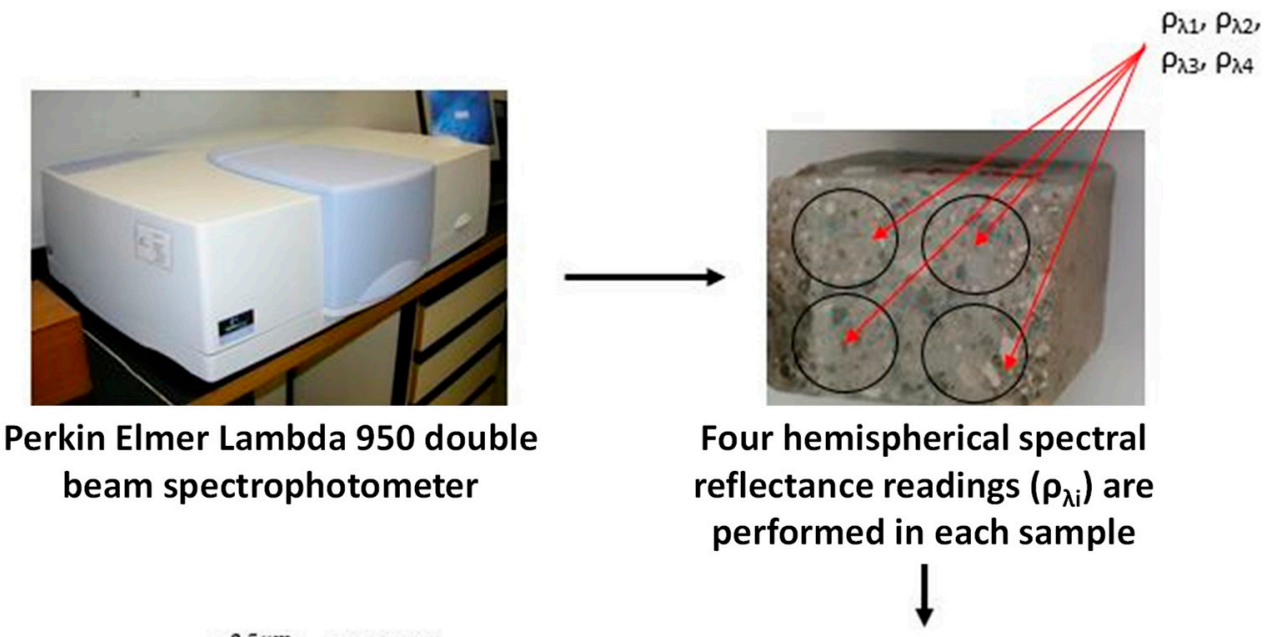

$$
\text { Albedo }=\frac{\int_{0.3 \mu \mathrm{m}}^{2.5 \mu \mathrm{m}} \rho_{\lambda} G_{b}(\lambda) d \lambda}{\int_{0.3 \mu \mathrm{m}}^{2.55 \mathrm{~m}} G_{b}(\lambda) d \lambda}
$$

$\mathrm{Gb} \lambda$

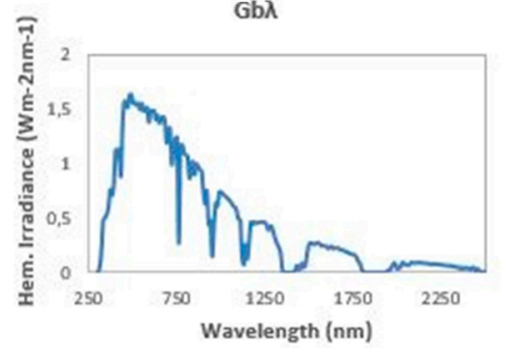

Mean value $\left(\rho_{\lambda}\right)$ and standard deviation $(\sigma)$ of four readings are calculated for each sample:

$$
\begin{gathered}
\rho_{\lambda}=\frac{\rho_{\lambda 1}+\rho_{\lambda 2}+\rho_{\lambda 3}+\rho_{\lambda 4}}{4} \\
\sigma=\sqrt{\frac{\sum_{i=1}^{n}\left(\rho_{\lambda i}-\rho_{\lambda}\right)^{2}}{n-1}}
\end{gathered}
$$

Figure 3. Schematic diagram of the testing procedure.

An albedo with an air mass of 1.5 refers to a surface's ability to reflect sunlight that has a spectral irradiance distribution characteristic of having traversed an atmospheric path length equal to 1.5 times the height of the earth's atmosphere. This path length corresponds to a solar altitude of $42^{\circ}$. An irradiance with an air mass of 1.5 is representative of average conditions in the contiguous United States (ASTM 1998).

\section{Results}

Table 3 shows the average albedo results and their standard deviations obtained in the tested precast pavements. Albedo values of PVT samples ranged from 0.13 to 0.6 , while Sailo values ranged from 0.25 to 0.79 . In addition, the PVT sample readings were less homogeneous than the Sailo ones.

Only two samples had albedo values below 0.20 (PVT 9 \& PVT 12). Both paving materials were made with dark grey Portland cement and fine siliceous aggregates. By contrast, the highest albedo was measured in PVT 5 (0.60), which was made with white Portland cement and marble powder as sand. PVT samples with the lowest and highest albedo measurements are shown in Figure 4.

The highest albedo value in the Sailo samples was measured in the white precast concrete (0.79) followed by the Pantone ${ }^{\circledR}$ Yellow $012(0.62)$ and albero yellow $(0.60)$ ones. Their hemispherical spectral reflectance is depicted in Figure 5 . The grey color precast concrete (0.40) and black tile (0.40) samples also presented very high albedo values. Finally, grey, black, and brown cobblestones exhibited lower values $(0.30,0.30$, and 0.26 , respectively), and their hemispherical spectral reflectance is shown in Figure 6. 
Table 3. Albedo average results and standard deviations obtained in the tested precast pavements.

\begin{tabular}{cccccc}
\hline PVT Code & $\begin{array}{c}\text { Average } \\
\text { Result }\end{array}$ & $\begin{array}{c}\text { Standard } \\
\text { Deviation }\end{array}$ & Sailo Code & $\begin{array}{c}\text { Average } \\
\text { Result }\end{array}$ & $\begin{array}{c}\text { Standard } \\
\text { Deviation }\end{array}$ \\
\hline PVT-1 & 0.35 & 0.01 & Sailo-1 & 0.30 & 0.01 \\
PVT-2 & 0.23 & 0.03 & Sailo-2 & 0.30 & 0.00 \\
PVT-3 & 0.28 & 0.01 & Sailo-3 & 0.26 & 0.01 \\
PVT-4 & 0.44 & 0.04 & Sailo-4 & 0.39 & 0.01 \\
PVT-5 & 0.60 & 0.02 & Sailo-5 & 0.79 & 0.00 \\
PVT-6 & 0.37 & 0.02 & Sailo-6 & 0.60 & 0.01 \\
PVT-7 & 0.23 & 0.02 & Sailo-7 & 0.40 & \\
PVT-8 & 0.41 & 0.03 & Sailo-8 & & \\
PVT-9 & 0.14 & 0.02 & & & \\
PVT-10 & 0.40 & 0.01 & & & \\
PVT-11 & 0.58 & 0.01 & & & \\
PVT-12 & 0.13 & 0.01 & & & \\
PVT-13 & 0.25 & 0.02 & & & \\
PVT-14 & 0.44 & 0.01 & & & \\
PVT-15 & 0.18 & 0.03 & & & \\
PVT-16 & 0.27 & 0.04 & & & \\
PVT-17 & 0.40 & 0.01 & & & \\
PVT-18 & 0.29 & 0.02 & & & \\
PVT-19 & 0.44 & 0.01 & & \\
PVT-20 & 0.24 & 0.04 & & & \\
PVT-21 & 0.24 & 0.03 & & \\
PVT-22 & 0.33 & 0.01 & & \\
PVT-23 & 0.43 & 0.01 & & & \\
PVT-24 & 0.44 & 0.02 & & & \\
PVT-25 & 0.47 & 0.02 & & & \\
PVT-26 & 0.54 & 0.00 & & & \\
PVT-27 & 0.39 & 0.00 & & & \\
PVT-28 & 0.57 & 0.01 & & & \\
PVT-29 & 0.60 & 0.02 & & & \\
PVT-30 & 0.27 & 0.02 & & & \\
\hline
\end{tabular}

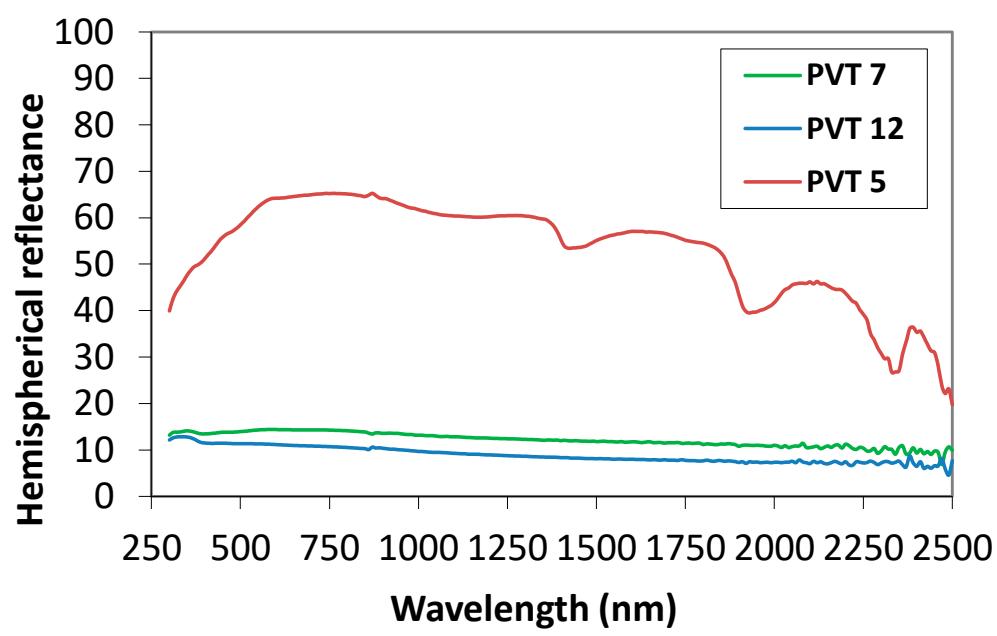

Figure 4. Hemispherical spectral reflectance of main PVT samples. 


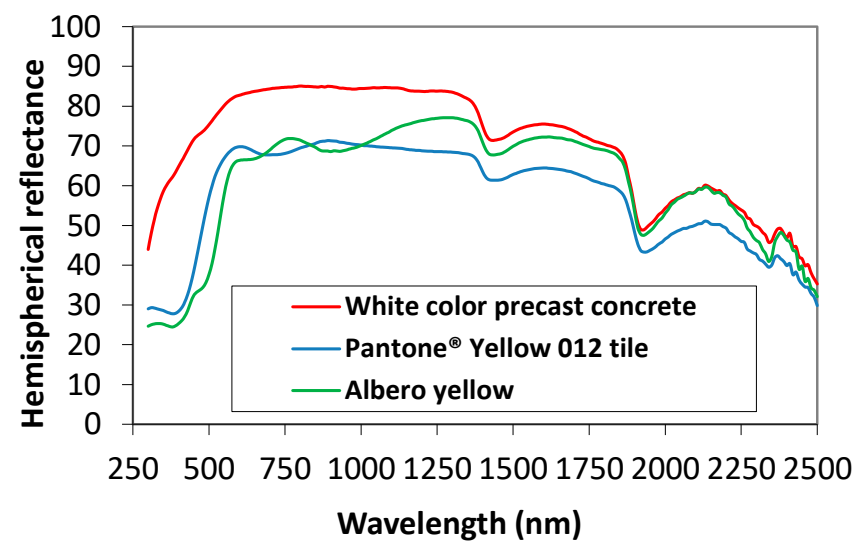

Figure 5. Hemispherical spectral reflectance of Sailo samples with the highest measured albedos.

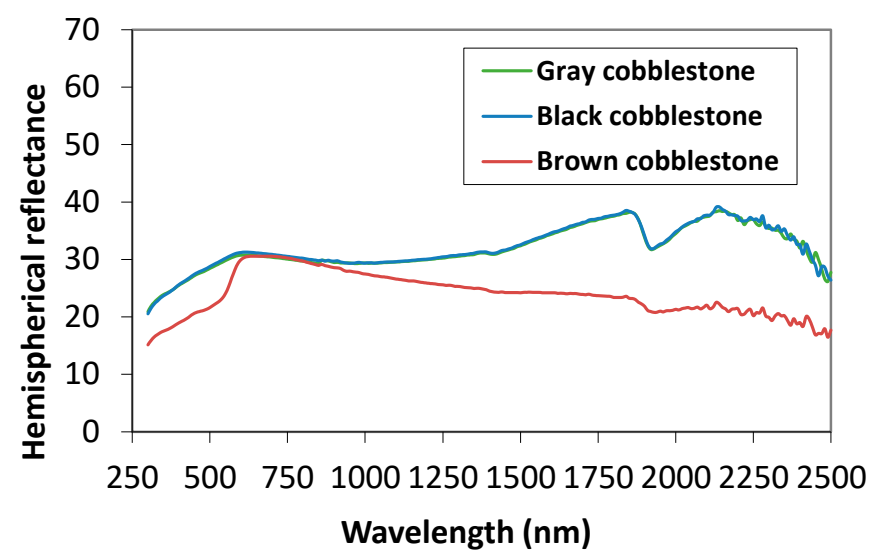

Figure 6. Hemispherical spectral reflectance of Sailo samples with the lowest measured albedos.

\section{Discussion}

As expected, clear colors (white and yellow) provide high reflective surfaces with albedo measurements between 0.6 and 0.8. Similar results have been reported in the literature $[8,17,24]$. Nevertheless, grey precast concrete and black tiles with clear color aggregates also provide high albedo measurements. Figure 7 shows the absolute frequency of each of the albedo values measured in all the tested samples. Most of them are in the range of $0.2-0.5$. Therefore, concrete has an average albedo of 0.35 , while new asphalt has an albedo between 0.05 and 0.10 and increases to $0.10-0.15$ upon aging [26]. Accordingly, the use of concrete pavements helps to reduce the temperature increase experienced in the Earth's surface, mitigating the impacts of climate warming.

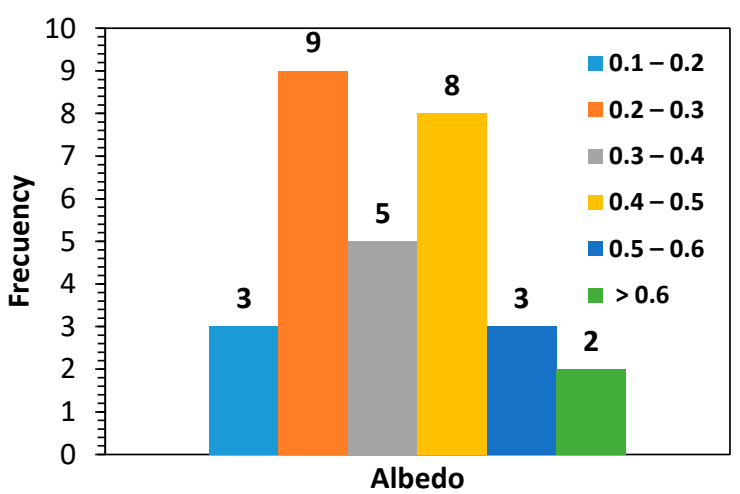

(a)

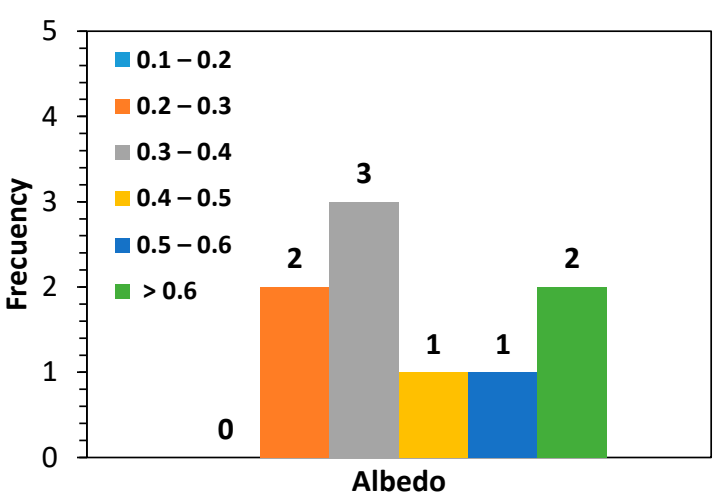

(b)

Figure 7. Absolute frequency of the albedo values measured in: (a) PVT samples; (b) Sailo samples. 
Among the samples, dark concretes were also represented with an average albedo of $0.2-0.3$. However, most samples showed very high reflectivity conditions $(0.4-0.6)$.

Concrete is normally considered to be a cool material within the LEED certification context by having a solar reflectance index (SRI) larger than 0.29 . This threshold value can be achieved for most of the concrete mixes. Furthermore, the highest albedo values can be achieved with concretes made with white Portland cement, white sand, and white coarse aggregates [17]. The solar reflectance index (SRI) is considered in the LEED criterion for cool pavements (SRI > 29) [17]. This index considers both solar reflectance and thermal emissivity, and it is calculated following the procedure given in the ASTM E 1980 (2013). Thermal emissivity is the ratio between the radiant flux emitted by a surface at an established temperature and by a black body radiator at that temperature. Measured thermal emissivity values for concrete pavements range from 0.90 to 0.98 [29]. The solar reflectance index (SRI) provides a measure related to the standard white and standard black colors, i.e., solar reflectance index equal to 100 (solar reflectance $=0.8$ and thermal emissivity $=0.9$ ) and null (solar reflectance $=0.05$ and thermal emissivity $=0.9$ ), respectively. White Portland cements present the same characteristics as grey Portland cements, except for color, and they are often used to produce white or colored concrete. Some good examples of white concrete applications are The Jubilee Church in Rome, Italy (Richard Meier, 1996-2003) and The City of Arts and Science in Valencia, Spain (Santiago Calatrava and Félix Candela, 1996-2009). Promotion of this type of buildings will contribute quite positively to the local climate. By contrast, coal fly ash cements reduce the solar reflectance of concrete [24,30]. Nevertheless, blended cements decrease the carbon footprint of concrete production.

Figure 8 shows several pavement applications and the albedo of such applications. The first photograph on the left is a pavement made with white cement and a very fine and clear aggregate (PVT-26). Consequently, it presents a high albedo of 0.54 . The second photograph shows a combination of two types of pavements, PVT-11 (0.58) and PVT-16 (0.27). The first one was made with white cement and calcareous and siliceous sand, whereas the second one was made with a mixture of grey and white cement. Finally, the photograph on the right presents three different types of paving materials with high, medium, and low albedo characteristics: PVT-5 (0.60), PVT-1 (0.35), and PVT-9 (0.15). In fact, the use of cool colored materials, namely yellow (Sailo 4 \& Sailo 5 samples), increases albedo substantially without altering visual appearance. Nevertheless, the effect of albedo variation on thermal sensation could be negative since the human body is non-selective in its absorption of solar energy [31].

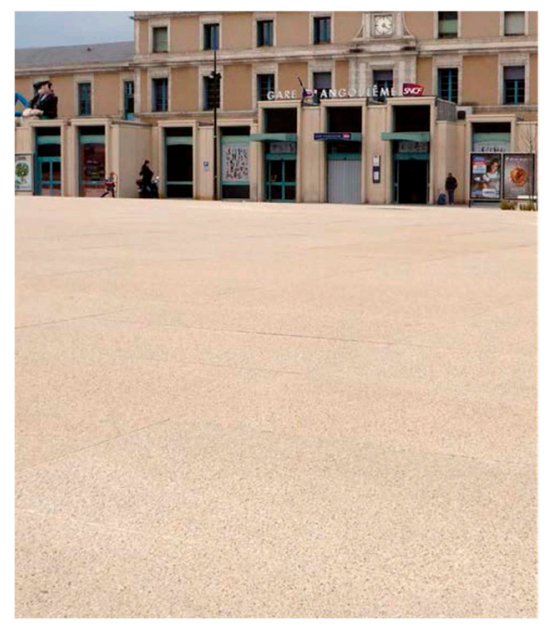

(a)

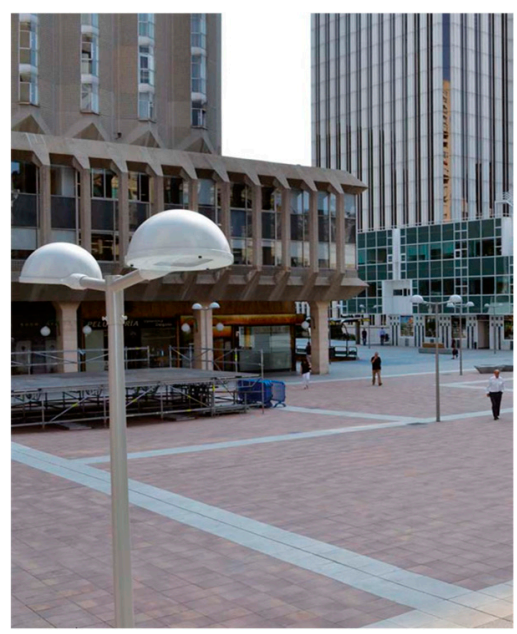

(b)

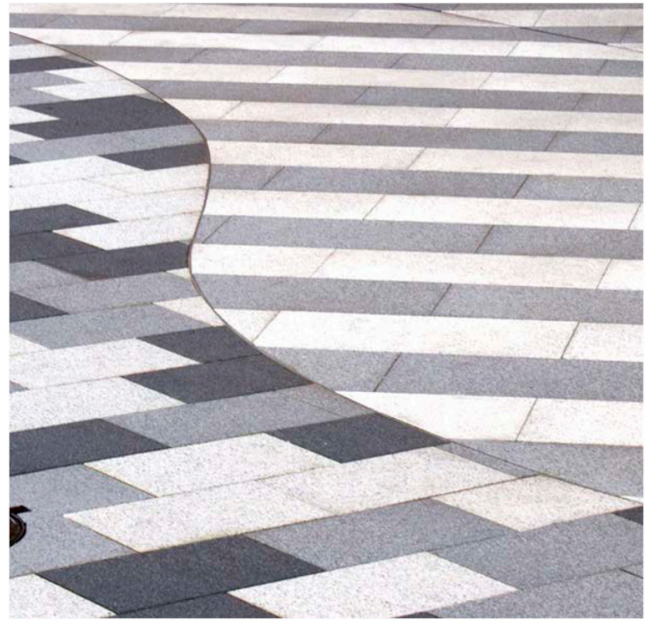

(c)

Figure 8. Albedo in some pavement applications: (a) PVT-26 (0.54); (b) PVT-11 (0.58) and PVT-16 (0.27); (c) PVT-5 (0.60), PVT-1 (0.35), and PVT-9 (0.15). 
To conclude, the use of cool pavements (i.e., concrete pavements) displays different mitigation performances depending on the mix design characteristics. However, concrete pavements contribute efficiently to climate change mitigation by lowering the earth's surface temperature. Hence, a variation in the earth's albedo can decrease the amount of energy that is absorbed. Table 4 presents some estimations of lowering the earth's surface temperature by increasing the average albedo by using concrete pavements instead of asphalt ones. An increase in albedo of 0.1 corresponds to a change of $34.1 \mathrm{~W} \mathrm{~m}^{-2}$ and a "carbon dioxide equivalent" reduction of $25 \mathrm{kgCO}_{2} / \mathrm{m}^{2}$ of pavement. The albedo of asphalt pavement (0.1) was used in the calculations as a reference value.

Table 4. Reduction of carbon dioxide emissions by using concrete pavements with different albedo values calculated taking the albedo of asphalt pavements as a reference.

\begin{tabular}{|c|c|c|c|}
\hline Pavement & Albedo & Reduction of Solar Flux $\left(\mathrm{W} \mathrm{m}^{-2}\right)$ & $\begin{array}{l}\text { Equivalent Emissions } \\
\text { Reduction }\left(\mathrm{kgCO}_{2} / \mathrm{m}^{2}\right)\end{array}$ \\
\hline Asphalt & 0.1 & 0 & 0 \\
\hline Concrete & 0.41-0.77 (average: 0.59) & $106-228(167)$ & $78-168(123)$ \\
\hline Concrete subjected to abrasion & $0.22-0.58$ (average: 0.40 ) & $41-164(102)$ & $30-120(75)$ \\
\hline Blast-furnace cement concrete & 0.582 & 164.4 & 120.5 \\
\hline
\end{tabular}

The albedo of concrete pavements can be up to seven times higher than that of asphalt pavements (Table 4). Consequently, this type of pavements can reflect between 40 and $200 \mathrm{~W} \mathrm{~m}^{-2}$ of the incident radiation with respect to asphalt pavements. This fact implies a substantial reduction in the earth's surface temperature, equivalent to a decrease of $30-168 \mathrm{kgCO}_{2} / \mathrm{m}^{2}$.

In the case that the Spanish freeways $(17,377 \mathrm{~km})$ were built with concrete with an albedo of 0.15 , with a reduction of $25 \mathrm{kgCO}_{2} / \mathrm{m}^{2}$ of pavement, the radiation sent back into the atmosphere would be equivalent to the reduction of carbon dioxide of 13.9 million tons each year, directly offsetting global warming. For instance, a hypothetical albedo of 0.4 for the Spanish freeway network will provide an equivalent carbon dioxide lowering of $75 \mathrm{kgCO}_{2} / \mathrm{m}^{2}$ of pavement/year and, therefore, equivalent to the reduction of carbon dioxide of 27.4 million tons. Considering an average service life of the concrete pavements of 50 years, the total carbon dioxide reduction would be 695-1370 million tons. Accordingly, high-albedo pavements transform the freeway surface that would otherwise intensify the temperature increase into one that addresses both the cause and consequence of climate change.

Then, concrete pavements contribute efficiently to climate change mitigation by lowering the earth's surface temperature. In addition, it is worth remembering that concrete is fully recyclable at the end of its service life and local resources are used for the manufacture of concrete pavements.

\section{Conclusions}

The following conclusions are based on the solar reflectance measurements of 38 precast concrete pavement specimens from different concrete mixes representing the entirety of the precast concrete pavements produced in Spain:

1. Concrete pavements can contribute very efficiently to climate change mitigation by lowering the earth's surface temperature, which is equivalent to a reduction of $25-75 \mathrm{kgCO}_{2} / \mathrm{m}^{2}$. Therefore, if concrete pavements were used on the entire Spanish network of freeways and motorways, a yearly carbon dioxide reduction of $13.9-27.4$ million tons is expected. This value is about $0.5-1 \%$ of the global emission of the cement sector (2.9 $10^{9}$ in 2016). 
2. A global carbon dioxide reduction of 0.7-1.4 gigatons can be achieved by replacing the Spanish freeway conventional asphalt pavements with cool high-reflective concrete ones, considering an average service life of 50 years for concrete pavements.

3. Most precast concrete pavements in this research program have average solar reflectance values above 0.30 (i.e., SRI of at least 29). Accordingly, they meet the requirements of LEED-NC SS 7.1.

4. Local climate change mitigation will be improved by replacing asphalt pavements with concrete ones in the Spanish freeway network

5. Concrete, which is a fully recyclable paving material made with local resources can be successfully used for the manufacture of cool pavements replacing conventional asphalt.

Future work will consider the effect of aging on the concrete albedo. As concrete ages, it tends to darken because aging leads to high levels of dirt particles and tire wear on the pavements. Therefore, it is expected that older concretes have lower albedos than new ones. Our future work will take the effect of the age on existing concrete albedo into account. Certain approaches will also be pointed out in future work with respect to optimizing the performance of concrete pavements.

Author Contributions: Conceptualization, A.Z., M.Á.S. and Á.M.; methodology, Á.M. and M. Á.S.; software, Á.M. and M.Á.S.; validation, Á.M. and M.Á.S.; formal analysis, Á.M. and M.Á.S.; investigation, A.Z., M.Á.S. and Á.M.; resources, A.Z.; data curation, Á.M. and M.Á.S.; writing-original draft preparation, M.Á.S.; writing—review and editing, M.Á.S. and Á.M.; visualization, A.Z., M.Á.S. and Á.M.; supervision, A.Z.; project administration, A.Z.; funding acquisition, A.Z. All authors have read and agreed to the published version of the manuscript.

Funding: This research received no external funding.

Institutional Review Board Statement: Not applicable.

Informed Consent Statement: Not applicable.

Data Availability Statement: Not applicable.

Acknowledgments: The authors would like to thank the following people who assisted in providing the samples and technical data to perform the experiment presented in this paper: Jesús Chirinos, PVT, and Nicolás Bonilla, SAILO.

Conflicts of Interest: The authors declare no conflict of interest.

\section{References}

1. Mofidi, F.; Akbari, H. Intelligent buildings: An overview. Energy Build. 2020, 223, 110192. [CrossRef]

2. Akbari, H.; Cartalis, C.; Kolokotsa, D.; Muscio, A.; Pisello, A.L.; Rossi, F.; Santamouris, M.; Synnef, A.; Wong, N.H.; Zinzi, M. Local climate change and urban heat island mitigation techniques-The state of the art. J. Civ. Eng. Manag. 2016, 22, 1-16. [CrossRef]

3. Rosenfeld, A.H.; Akbari, H.; Romm, J.J.; Pomerantz, M. Cool communities: Strategies for heat island mitigation and smog reduction. Energy Build. 1998, 28, 51-62. [CrossRef]

4. Cotana, F.; Rossi, F.; Filipponi, M.; Coccia, V.; Pisello, A.L.; Bonamente, E.; Cavalaglio, G. Albedo control as an effective strategy to tackle Global Warming: A case study. Appl. Energy 2014, 130, 641-647. [CrossRef]

5. Santamouris, M.; Gaitani, N.; Spanou, A. Using cool paving materials to improve microclimate of urban areas-Design realization and results of the Flisvos project. Build. Environ. 2012, 53, 128-136. [CrossRef]

6. Battisti, A.; Laureti, F.; Zinzi, M.; Volpicelli, G. Climate Mitigation and Adaptation Strategies for Roofs and Pavements: A Case Study at Sapienza University Campus. Sustainability 2018, 10, 3788. [CrossRef]

7. Diz-Mellado, E.; López-Cabeza, V.P.; Rivera-Gómez, C.; Roa-Fernández, J.; Galán-Marín, C. Improving School Transition Spaces Microclimate to Make Them Liveable in Warm Climates. Appl. Sci. 2020, 10, 7648. [CrossRef]

8. Pisello, A.L.; Pignatta, G.; Castaldo, V.L.; Cotana, F. Experimental Analysis of Natural Gravel Covering as Cool Roofing and Cool Pavement. Sustainability 2014, 6, 4706-4722. [CrossRef]

9. Sen, S.; Roesler, J.; Ruddell, B.; Middel, A. Cool Pavement Strategies for Urban Heat Island Mitigation in Suburban Phoenix, Arizona. Sustainability 2019, 11, 4452. [CrossRef]

10. Fernandez-Antolin, M.-M.; del-Río, J.-M.; Gonzalez-Lezcano, R.-A. Influence of Solar Reflectance and Renewable Energies on Residential Heating and Cooling Demand in Sustainable Architecture: A Case Study in Different Climate Zones in Spain Considering Their Urban Contexts. Sustainability 2019, 11, 6782. [CrossRef] 
11. Tsoka, S.; Tsikaloudaki, K.; Theodosiou, T.; Bikas, D. Urban Warming and Cities' Microclimates: Investigation Methods and Mitigation Strategies-A Review. Energies 2020, 13, 1414. [CrossRef]

12. Zhang, Y.; Wei, P.; Wang, L.; Qin, Y. Temperature of Paved Streets in Urban Mockups and Its Implication of Reflective Cool Pavements. Atmosphere 2021, 12, 560. [CrossRef]

13. Oropeza-Perez, I. Simplified Numerical Model for Analyzing the Effects of the Urban Heat Island upon Low-Rise Buildings by Using a Free-License Thermal Simulation Program. Urban Sci. 2020, 4, 30. [CrossRef]

14. Sanjuán, M.Á.; Suarez-Navarro, J.A.; Argiz, C.; Mora, P. Assessment of radiation hazards of white and grey Portland cements. J. Radioanal. Nucl. Chem. 2019, 322, 1169-1177. [CrossRef]

15. Sanjuán, M.Á.; Esteban, E.; Argiz, C.; del Barrio, D. Effect of curing time on granulated blast-furnace slag cement mortars carbonation. Cem. Concr. Compos. 2018, 90, 257-265. [CrossRef]

16. Gaedicke, C.; Marines, A.; Mata, L.; Miankodila, F. Effect of recycled materials and compaction methods on the mechanical properties and solar reflectance index of pervious concrete. Rev. Ing. Constr. 2015, 30, 159-167. [CrossRef]

17. Levinson, R.; Akbari, H. Effects of composition and exposure on the solar reflectance of Portland cement concrete. Cem. Concr. Res. 2002, 32, 1679-1698. [CrossRef]

18. US Green Building Council (USGBC). LEED 2009 for New Construction and Major Renovations (Updated 2016); US Green Building Council: Washington, DC, USA, 2016; Available online: https://www.usgbc.org/resources/leed-new-construction-v2009current-version (accessed on 20 May 2021).

19. Grandi, C.; D’Ovidio, M.C. Balance between Health Risks and Benefits for Outdoor Workers Exposed to Solar Radiation: An Overview on the Role of Near Infrared Radiation Alone and in Combination with Other Solar Spectral Bands. Int. J. Environ. Res. Public Health 2020, 17, 1357. [CrossRef]

20. Saulat, H.; Cao, M.; Khan, M.M.; Khan, M.; Khan, M.M.; Rehman, A. Preparation and applications of calcium carbonate whisker with a special focus on construction materials. Constr. Build. Mater. 2020, 236, 117613. [CrossRef]

21. Cao, M.; Khan, M.; Ahmed, S. Effectiveness of Calcium Carbonate Whisker in Cementitious Composites. Period. Polytech. Civ. Eng. 2020, 64, 265-275. [CrossRef]

22. Khan, M.; Ali, M. Effectiveness of hair and wave polypropylene fibers for concrete roads. Constr. Build. Mater. 2018, 166, 581-591. [CrossRef]

23. Khan, M.; Rehman, A.; Ali, M. Efficiency of silica-fume content in plain and natural fiber reinforced concrete for concrete road. Constr. Build. Mater. 2020, 244, 118382. [CrossRef]

24. Marceau, M.L.; VanGeem, M.G. Solar Reflectance of Concretes for LEED Sustainable Sites Credit: Heat Island Effect. SN2982; Portland Cement Association: Skokie, IL, USA, 2007; pp. 1-22.

25. The Ministry of Transport, Mobility and Urban Agenda of Spain (MITMA). 2018 Statistical Yearbook; MITMA: Madrid, Spain, November 2019. Available online: https:/ / www.mitma.gob.es/el-ministerio/informacion-estadistica/anuario-estadisticas-desintesis-y-boletin/anuario-estadistico/presentacionanuario2018 (accessed on 20 May 2021).

26. Cheela, V.R.S.; John, M.; Biswas, W.; Sarker, P. Combating Urban Heat Island Effect-A Review of Reflective Pavements and Tree Shading Strategies. Buildings 2021, 11, 93. [CrossRef]

27. Sanjuán, M.Á.; Andrade, C.; Mora, P.; Zaragoza, A. Carbon Dioxide Uptake by Cement-Based Materials: A Spanish Case Study. Appl. Sci. 2020, 10, 339. [CrossRef]

28. IPCC. 2021: Climate Change 2021: The Physical Science Basis. In Contribution of Working Group I to the Sixth Assessment Report of the Intergovernmental Panel on Climate Change; Masson-Delmotte, V., Zhai, P., Pirani, A., Connors, S.L., Péan, C., Berger, S., Caud, N., Chen, Y., Goldfarb, L., Gomis, M.I., et al., Eds.; Cambridge University Press: Cambridge, UK, October 2021. (in press)

29. Kaloush, K.E.; Carlson, J.D.; Golden, J.S.; Phelan, P.E. The Thermal and Radiative Characteristics of Concrete Pavements in Mitigating Urban Heat Island Effects. SN2969; Portland Cement Association: Skokie, IL, USA, 2008. Available online: http:/ / www.cement. org/bookstore/ download.asp?mediatypeid=1\&id=16866\&itemid=SN2969 (accessed on 19 May 2021).

30. Boriboonsomsin, K.; Reza, F. Mix design and benefit evaluation of high solar reflectance concrete for pavements. Transp. Res. Rec. 2007, 2011, 11-20. [CrossRef]

31. Erell, E.; Pearlmutter, D.; Boneh, D.; Kutiel, P.B. Effect of high-albedo materials urban street canyons. Urban Clim. 2014, 10 Pt 2, 367-386. [CrossRef] 